\title{
Study of effect of exchange transfusion in pre-term and term infants: A prospective study
}

\author{
Alaka Sahu ${ }^{1}$, Deepak Kumar Dasmohapatra ${ }^{2, *}$, Kailash Chandra Agrawal ${ }^{3}$ \\ ${ }^{\mathbf{1}}$ Associate Professor, ${ }^{2} \mathrm{PG}$ Tutor, ${ }^{3} \mathrm{HOD}$, Dept. of Pathology, Veer Surendra Sai Institute of Medical Sciences and Research, \\ Burla, Odisha, India
}

*Corresponding Author:

Email: dkdm@ rediffmail.com

Received: $1^{\text {st }}$ January, 2018

Accepted: $14^{\text {th }}$ February, 2018

\begin{abstract}
Hyperbilirubinemia is usually benign in preterm and term infants. Dangerous hyperbilirubinemia is uncommon but may cause long term neurological impairment. In a resource limited rural setup exchange transfusion is an easy, cheap and convenient way for treatment. Our Study focus to improve the outcome in neonatal Hyperbilirubinemia patients in a rural referral center of Odisha.

Aim: Our present study aims at determining the alternations of various haematological and biochemical parameters after exchange transfusion along with adverse outcomes in pre-term and term infants.

Materials and Methods: Total 106 new-borns blood samples were taken from those who have under gone exchange transfusion for different indications. New-borns are divided into two groups pre-term and term infants.

Results: A significant decrease in serum bilirubin values was observed in both the groups after exchange transfusion. Also a significant decrease in blood platelet and increase in calcium level were also present.

Conclusion: Proper approach and prompt management is needed in case of neonatal-hyperbilirubinemia in a resource limited rural setup.
\end{abstract}

Keywords: Exchange Transfusion, Hyperbilirubinemia.

\section{Introduction}

Normally bilirubin is formed from the metabolism of haeme, a component of red blood cell. Upon premature destruction of red blood cells there is increase in bilirubin concentration. Normally this process is physiological but in presence of certain conditions like autoimmune diseases of new-born bilirubin level may increases pathologically. ${ }^{1,2}$

Neonatal hyperbilirubinemia with elevation of serum bilirubin levels usually occurs in pre-term and term infants leading to morbidity but usually not life threatening. However, if serum bilirubin levels exceeds a dangerous limit, which varies with various factors like birth weight, gestational age, chronological age and rate of increase in un-conjugated bilirubin concentration, bilirubin may cross blood brain barrier as in neonates blood-brain barrier is not fully developed and bilirubin encephalopathy, kernicterus may occur. ${ }^{3-5}$

Severe hyperbilirubinemia occurs when the total serum bilirubin (TSB) concentration is $>340 \mu \mathrm{mol} / \mathrm{L}$ at any time during the first 28 days of life and critical hyperbilirubinemia occurs when the Total Serum Bilirubin concentration is $>425 \mu \mathrm{mol} / \mathrm{L}$ during the first 28 days of life. ${ }^{1}$

\section{Materials and Methods}

The present study was done in the Department of Pathology in association with the Department of Paediatrics in Veer Surendra Sai Medical College, Burla from period July 2016 to August 2017. All haematological parameters are measured in Regional Diagnostic Centre of our Medical College. A total of Hundred-six blood samples were analysed including both pre-term and term infants who had under-gone exchange transfusion. The pre-term and term infants were placed in Group A and Group B respectively.

Before Exchange Transfusion: Bilirubin, Hemoglobin,total Leukocyte count, platelets, blood urea and creatinine, serum electrolytes, total serum calcium, serum phosphate, c-reactive protein were measured in the first aliquot of blood drawn from the baby.

Post-Exchange Transfusion: At the end of the procedure the last aliquot of blood drawn from the baby was collected and all the above parameters were reestimated.

Exchange transfusion was done by standard pushpull method through umbilical route.

\section{Results}

Table 1: Details of Group A \& B infants studied

\begin{tabular}{|l|c|c|c|c|c|}
\hline Term Infants & \multicolumn{2}{|c|}{ Numbers \& sex } & \multicolumn{2}{|c|}{ Birth weight } & Gestational age(weeks) \\
\hline & M & F & Range & No of Infants & \\
\hline 39 & 25 & 14 & $2500-2999$ & 30 & \multirow{2}{*}{} \\
\cline { 4 - 6 } & & & $>3000$ & 9 & \\
\hline Pre-term infants & & & $<1000$ & 0 & \\
\hline
\end{tabular}




\begin{tabular}{|l|c|c|c|c|c|}
\hline 67 & 38 & 29 & & & \\
\cline { 4 - 5 } & & $1000-1499$ & 6 & $<28$ weeks \\
\cline { 4 - 5 } & & $1500-1999$ & 36 & $28-31$ weeks \\
\cline { 4 - 6 } & & $2000-2499$ & 25 & $32-36$ weeks \\
\hline
\end{tabular}

Table 2: Distribution of new-borns according to etiology of jaundice

\begin{tabular}{|l|c|c|c|}
\hline S. No. & Etiology & Group A $(\mathbf{n}=\mathbf{3 9})$ & Group B $(\mathbf{n}=\mathbf{6 7})$ \\
\hline 1. & Rh incompatibility & 4 & 7 \\
\hline 2. & ABO incompatibility & 15 & 24 \\
\hline 3. & Rh and ABO incompatibility & 3 & 5 \\
\hline 4. & Cephalhematoma & 1 & 0 \\
\hline 5. & Septicaemia & 9 & 19 \\
\hline 6. & Unknown & 7 & 12 \\
\hline
\end{tabular}

Table 3: Changes in haematological and bio-chemical parameters in admitted babies before and after exchange transfusion

\begin{tabular}{|l|c|c|c|}
\hline \multicolumn{1}{|c|}{ Hematological Parameters } & Pre-transfusion & Post-transfusion & P-Value \\
\hline Total bilirubin $\mu$ mol/L(mean(SD)) & $494.9(138.2)$ & $182.5(59.3)$ & $<0.001$ \\
\hline Direct bilirubin $\mu$ mol/L(median(range)) & $24(12.5-28.5)$ & $14.0(10.3-22.04)$ & 0.034 \\
\hline Haemoglobin $\mathrm{g} / \mathrm{dL}($ mean(SD)) & $14.0(3.2)$ & $14.3(1.9)$ & 0.638 \\
\hline White cell count $\times 10^{9} / \mathrm{L}(\mathrm{mean}(\mathrm{SD}))$ & $11.9(7.2-16.2)$ & $9.8(5.4-12.3)$ & 0.161 \\
\hline Platelets $\times 10^{9} / \mathrm{L}(\mathrm{mean}(\mathrm{SD}))$ & $225.6(121.1)$ & $135.9(86.7)$ & $<0.001$ \\
\hline Urea $\mathrm{mmol} / \mathrm{L}(\mathrm{mean}($ range) $)$ & $4.2(3.4)$ & $3.5(2.6)$ & 0.443 \\
\hline Creatinine $\mu \mathrm{mol} / \mathrm{L}($ median(range) $)$ & $44.5(31.3-59.5)$ & $51(33.0-64.5)$ & 0.211 \\
\hline Sodium mmol/L(median(range)) & $143.0(138.3-146.0)$ & $142.0(138.1-145.9)$ & 0.312 \\
\hline Potassium mmol/L(median(SD)) & $4.4(3.7-5.1)$ & $4.3(3.6-4.9)$ & 0.473 \\
\hline Calcium mmol/L(median(SD)) & $2.5(2.3-2.8)$ & $3.0(2.6-3.3)$ & $<0.001$ \\
\hline Magnesium mmol/L(median(SD)) & $0.91(0.76-0.97)$ & $0.88(0.78-0.95)$ & 0.606 \\
\hline Phosphate mmol/L(mean(range)) & $2.0(0.5)$ & $2.5(0.5)$ & 0.016 \\
\hline $\begin{array}{l}\text { C-reactive protein } \\
\text { mg/mL(median(range)) }\end{array}$ & $2.9(1.0-9.8)$ & $3.1(1.0-12.1)$ & 0.653 \\
\hline
\end{tabular}

\section{Discussion}

Neonatal jaundice leading to severe hyperbilirubinemia still remains a major problem in our Western Odisha. An exchange transfusion soon after birth is indicated if:

1. Cord bilirubin is $\geq 5 \mathrm{mg} / \mathrm{dl}$

2. Cord $\mathrm{Hb}$ is $\leq 10 \mathrm{~g} / \mathrm{dl}, \mathrm{PCV}<30$.

3. Previous sibling history and positive direct coomb test.

Subsequent exchange transfusion is indicated if:

1. Bilirubin $\geq 10 \mathrm{mg} / \mathrm{dl}$ within 24 hours of age.

2. Bilirubin $\geq 15 \mathrm{mg} / \mathrm{dl}$ between $25-48$ hours of age.

3. Bilirubin $\geq 20 \mathrm{mg} / \mathrm{dl}$ after 48 hours of age.

4. Rate of rise of bilirubin is $\geq 0.5 \mathrm{mg} / \mathrm{dl} / \mathrm{hr}$.

In exchange Transfusions infant's blood is exchanged with adult blood by conventional push-pull technique in $10 \mathrm{ml}$ aliquots. Total volume of donor's blood infused is usually $80 \mathrm{ml} / \mathrm{kg}$ body weight in a single volume of exchange transfusion, it replaces about $60 \%$ of the infant's blood volume and in double volume exchange transfusion $170 \mathrm{ml} / \mathrm{kg}$ body weight, where it replaces $85 \%$ of the blood volume. ${ }^{10} \mathrm{~A}$ significant proportion of serum bilirubin is removed from the body which ensures immediate protection against the imminent bilirubin toxicity. ${ }^{6,11}$ Phototherapy is an effective way of decreasing the bilirubin level in neonates, by converting un-conjugated bilirubin into isomers like lumirubin that are water soluble and can be excreted in the urine. ${ }^{7,12}$ Exchange transfusion however, is considered to be the most effective and quickest method to lower the bilirubin level in infants at high risk of kernicterus. ${ }^{13,14}$ An ET is indicated when hyperbilirubinemia remains at dangerous levels despite intensive phototherapy and is particularly useful when there is excessive haemolysis. ${ }^{13,15}$ In the present study, most babies with hyperbilirubinemia were male, breastfed, and delivered vaginally. ${ }^{2}$

The present study highlights the fact that there are two populations of new-born babies who undergo exchange transfusion, premature and sick babies who remain in hospital after birth and well term babies who are discharged after birth. The prevention of severe hyper-bilirubinemia is different for these two groups. For all babies, it is important to know the mother's blood group and to screen babies for jaundice in the first 48 hours after birth. 
In the present study, out of 106 new-borns, 63\% (67) were low birth weight. In group A, 77\% new-borns had their birth weights in the range of 2500-2999 grams, while only $23 \%$ were $>3000$ grams. All new-borns in group A were term (37-41 weeks). In group B, maximum $53.73 \%$ new-borns had their birth weight in the range of 1500-1999 grams and $37.31 \%$ in the range of 2000-2499 grams.

Increased incidence of neonatal hyperbilirubinemia in preterm and low birth weight babies can be explained on the basis of hepatic immaturity. ${ }^{15}$

Our study found that maximum number of new-borns who were exchanged for jaundice had $\mathrm{ABO}$ incompatibility i.e. $38.46 \%$ in group A and $35.82 \%$ in group B. In the present study second-most common cause for exchange in new born is sepsis i.e.23.07\% in group A and $28.35 \%$ in group B, which directly reflects lack of proper education and poor health services in villages of western Odisha. Only a single case of Cephalhematoma was documented. In $17.92 \%$ cases the aetiology of jaundice could not be determined. In the present study we found that there is a significant decrease in serum bilirubin levels post-exchange transfusion. Though phototherapy is very much popular in the management of neonatal jaundice but to avoid the risk of bilirubin encephalopathy exchange transfusion is the method of choice. ${ }^{16}$ In our study post exchange transfusion Thrombocytopenia is a major adverse event. ${ }^{17}$

In the present study mean Post Exchange total calcium level was significantly higher than the preexchange total calcium level $(\mathrm{p}<0.001)$. This transient rise of total calcium level was associated with routine use of intravenous administration of $10 \%$ calcium gluconate after each $100 \mathrm{ml}$ of blood exchange in order to counteract any fall in serum ionized calcium levels. ${ }^{18}$ Such fall occurs due to calcium chelating properties of citrate which is present in high concentration in the donor's blood where it is used as an anticoagulant. ${ }^{17,18}$ Calcium level came within the normal range after 24 hours of transfusion.

Among rest of the parameters haemoglobin and total leucocyte count shows a little improvement after exchange transfusions.

\section{Conclusion}

Neonatal Hyper-bilirubinemia is still a one of the major health hazards in neonates but should largely be preventable if health care personnel's give emphasis on prompt management as per the recommendations. We recommends to give emphasize on the importance of universal, systematic assessment towards the risk factors of severe hyperbilirubinemia, close follow-up, and prompt intervention, when necessary. Careful monitoring of the risk factors involved a systematic approach to the detection and follow-up of neonatal jaundice cases with appropriate laboratory investigations, along with judicious exchange transfusion when indicated, are the best approach to avoid complications in a rural setup.

\section{Conflict of Interest: None.}

\section{References}

1. Stevenson DK, Fanaroff AA, Maisels MJ, et al. Prediction of hyperbilirubinemia in near term and term infants. Pediatrics. $2001 \mathrm{Jul} ; 108(1): 31-9$.

2. Olusanya BO, Osibanjo FB, Slusher TM. (2015). Risk factors for severe neonatal hyperbilirubinemia in low and middle-income countries: a systematic review and metaanalysis. PLoS One, 10 (2):e0117229.

3. Burke BL, Robbins JM, Bird TM, Hobbs CA, Nesmith C, Tilford JM. (2009). Trends in hospitalizations for neonatal jaundice and kernicterus in the United States, 1988-2005. Pediatrics, 123:524-32.

4. Paludetto R, Mansi G, Raimondi F, Romano A, Crivaro V, Bussi M, D’ Ambrosio G. (2002). Moderate hyperbilirubinemia induces a transient alteration of neonatal behavior. Pediatrics, 110:e50.

5. Nass RD, Frank Y. (2010). Cognitive and Behavioral Abnormalities of Pediatric Diseases. $1^{\text {st }}$ ed. Oxford University Press.

6. Huang MJ, Kua KE, Teng HC, Tang KS, Weng HW, Huang CS. (2004). Risk factors for severe hyperbilirubinemia in neonates. Pediatr Res, 56(5):682-9.

7. R. Pratesi, G. Agati, and F. Fusi, "Phototherapy for neonatal hyperbilirubinemia," Photodermatology, vol. 6, no. 6, pp. 244-257, 1989.

8. Mishra S, Agarwal R, Deorari AK, Paul VK. (2008). Jaundice in the newborns. Indian J Pediatr, 75( 2):157-163.

9. Cloherty, J.P. and Stark, P.A.: Manual of neonatal care, 33rd Ed. Little Brown and Co. 1982.

10. Royal Hobart Hospital, Hobart, Clinical Practice Guidelines, Exchange Transfusion (NEO-1-0013): Neonatal Guideline, 2009.

11. R. Pratesi, G. Agati, and F. Fusi, "Phototherapy for neonatal hyperbilirubinemia," Photodermatology, vol. 6, no. 6, pp. 244-257, 1989.

12. T.B. Newman and M.J. Maisels, "Evaluation and treatment of jaundice in the term newborn: a kinder, gentler approach," Pediatrics, vol.89, no.5, part 1, pp.809-818,1992.

13. American Academy of Pediatrics and Provisional Committee for Quality Improvement and Subcommittee on Hyperbilirubinemia, "Practice parameter: management of hyperbilirubinemia in the healthy term new born," Pediatrics, vol.94, no.4, part 1, pp.558-565,1994.

14. Singh M, Singh M, Tiwari S. Effect of exchange transfusion in bilirubin and calcium level in Neonatal Hyperbilirubinemia. Int J Med Res Rev 2015;3(7):733737. doi: 10.17511/ijmrr.2015.i7.138

15. Bowman $\mathrm{J}$, The management of haemolytic diseases in the fetus and new born, semin perinatal, 1997;21:39-44.

16. Patra S, stofer-isser A, Siner B, Moore J, Hack M. Adverse events associa 18. Wexler IB, Pincus JB, Natelson S, Lugovoy JK. The fate of citrate in erythroblastic infants treated with exchange transfusion. $J$ Clin Invest. 1949 May;28(3):474-81.

17. Patra K, Storfer-Isser A, Siner B, Moore J, Hack M. Adverse events associated with neonatal exchange transfusion in the 1990s. J Pediatr 2004;144:626-31. 
18. Radde IC, Parkinson DK, Höffken B, Appiah KE, Hanley WB. Calcium ion activity in the sick neonates: Effect of bicarbonate administration and exchange transfusion. Pediatr Res. 1972 Jan;6(1):43-9.

19. Gershanik JJ, Levkoff AH, Duncan R. Serum ionized calcium values in relation to exchange transfusion. $J$ Pediatr._1973 May;82(5):847-50.

How to cite this article: Sahu A, Dasmohapatra DK, Agrawal KC. Study of effect of exchange transfusion in pre-term and term infants: A prospective study. Ind J Pathol Oncol, 2018;5(3):494-497. 